\title{
Article
}

\section{Familial Resemblance in Body Shape and Composition, Metabolic Syndrome, Physical Activity and Physical Fitness: A Summary of Research in Portuguese Families and Siblings}

\author{
Sara Pereira ${ }^{1}$, Carla Santos ${ }^{1}$, Peter T. Katzmarzyk ${ }^{2}$ and José Maia ${ }^{1}$ \\ $\left.{ }^{1} \mathrm{CIFI}\right|^{2} \mathrm{D}$, Faculty of Sport, University of Porto, Porto, Portugal and ${ }^{2}$ Pennington Biomedical Research Center, Louisiana State University, Baton Rouge, LA, USA
}

\begin{abstract}
We report a summary of Portuguese families and siblings research under the umbrella of the Portuguese Healthy Family Project. Families lived in mainland Portugal, as well as in the Azores and Madeira islands. All samples comprise children and adolescents (9-20 years) and their parents (27-57 years). Recruitment procedures and phenotypes were detailed. Familial resemblance in body shape and composition, metabolic syndrome, physical fitness, physical activity and sedentary behaviors are presented, as well as future research avenues.
\end{abstract}

Keywords: Families; siblings; similarity; somatotype; body composition; behavioral characteristics; health markers

(Received 27 May 2019; accepted 12 June 2019; First Published online 6 August 2019)

\section{Brief History}

Under the umbrella of the Portuguese Healthy Family Study, we designed and conducted seven substudies aimed at increasing our understanding of familial resemblance in body shape and composition, metabolic syndrome, physical activity and physical fitness. These studies had different degrees of complexity in terms of sample sizes, sets of phenotypes and geographical locations. In the first substudy, 'Genetic and Environmental Factors in Physical Activity Levels of Portuguese Familes', we sampled 3378 nuclear families (12,385 subjects) from mainland Portugal (Pereira et al., 2018a; Seabra et al., 2008) and focused largely on familial resemblance in physical activity phenotypes. The second substudy, 'Physical Activity and Metabolic Syndrome' (Campos, Maia, da Silva et al., 2007; Campos, Maia, Seabra et al., 2007), was geographically located in the Azores islands and included 133 nuclear families (410 subjects) aiming to best understand familial links between physical activity and metabolic syndrome. Substudy 3, 'Healthy Camacha: The Study in St. Cruz Families' (Maia et al., 2008), was located in the Madeira islands. Two hundred and ninety subjects (88 families) were assessed on physical activity, body composition, nutritional habits, health perceptions and metabolic syndrome. Substudy 4, 'Active Vouzela: An Auxological and Epidemiological Study’ (Maia et al., 2009), gathered information on 260 families (802 subjects) to explore familial resemblance in body composition, physical activity, nutritional behaviors, metabolic syndrome and household location. The fifth substudy, 'Heathy Living in St. Tirso: A Three-year Longitudinal Study', investigated families across 3 years (year 1, 63 families; year

\footnotetext{
Author for correspondence: José Maia, Email: jmaia@fade.up.pt
}

Cite this article: Pereira S, Santos C, Katzmarzyk PT, and Maia J. (2019) Familial Resemblance in Body Shape and Composition, Metabolic Syndrome, Physical Activity and Physical Fitness: A Summary of Research in Portuguese Families and Siblings. Twin Research and Human Genetics 22: 651-659, https://doi.org/10.1017/thg.2019.46
2, 78 families, year 3, 44 families). More than 1000 children and adolescents were followed for 3 consecutive years, and the phenotypes of interest included body composition, health perceptions, physical activity, nutritional behaviors, metabolic syndrome and bone health. The sixth substudy, 'Genetic and Environmental Factors in Physical Activity, Nutrition, Health Perceptions, Body Composition, and Metabolic Syndrome', concentrated its aims on the genetic and environmental architecture of links among physical activity, nutrition, health perceptions, body composition and metabolic syndrome. Finally, the seventh substudy, 'The Portuguese Sibling Study on Growth, Fitness, Lifestyle and Health', investigated physical growth, body composition, physical fitness, physical activity, metabolic syndrome and health behaviors in a cohort of siblings (1583 siblings pairs aged 9-20 years).

\section{Recruitment Procedures}

Our main recruitment sites were Portuguese public schools located in mainland Portugal, and the Azores and Madeira Islands. Our modus operandi was always the same: first, the principal investigator presented the protocol to the board of directors of each school; second, if accepted, the study aims and methodology were presented to the Physical Education teachers whose help was vital to contact students, mostly in their classes, and from students to their families; third, children and adolescents were invited to participate in the study along with their siblings and parents; fourth, the research team contacted all families interested in participating and was available to respond to all questions parents might like to ask.

All projects were approved by the ethics committee of the Faculty of Sport, University of Porto, and written informed consent was obtained from all subjects including the legal representatives of all youth. 
Table 1. Common domains, phenotypes, methods and instrumentation used in the Portuguese Healthy Family Study

\begin{tabular}{|c|c|c|}
\hline Domains & Phenotypes & Methods and instrumentation \\
\hline \multicolumn{3}{|l|}{ Biological } \\
\hline Body shape & Somatotype & Heath \& Carter anthropometric-based method \\
\hline Body composition & $\begin{array}{l}\text { Percentage body fat; percentage trunk, arm } \\
\text { and leg fat; total lean body mass (kg); trunk, } \\
\text { arm and leg mass (kg); Body Mass Index } \\
\text { (BMI) }\end{array}$ & Tanita BC-418 MA scale \\
\hline Metabolic syndrome & $\begin{array}{l}\text { Glucose, triglycerides, HDL-cholesterol, blood } \\
\text { pressure, waist circumference }\end{array}$ & $\begin{array}{l}\text { OMRON - M10 IT } \\
\text { Cholestech LDX analyzers }\end{array}$ \\
\hline Health-related physical fitness & $\begin{array}{l}\text { Morphological (waist circumference and } \\
\text { percentage body fat); muscular (handgrip } \\
\text { strength, standing long jump, curl-up, } \\
\text { push-up and trunk lift); motor ( } 50 \text {-yard dash } \\
\text { and shuttle run); cardiorespiratory } \\
\text { (1-mile run/walk) }\end{array}$ & $\begin{array}{l}\text { Fitnessgram test battery equipment } \\
\text { Fitnessgram and AAPHERD test battery } \\
\text { equipment }\end{array}$ \\
\hline Bone health & Bone density & Hologic Sahara Bone Ultrasound Densitometer \\
\hline \multicolumn{3}{|l|}{ Behavioral } \\
\hline Physical activity & $\begin{array}{l}\text { Total physical activity, physical activity at } \\
\text { work/school, leisure-time, sport participation }\end{array}$ & Baecke questionnaire \\
\hline Sedentary behavior & $\begin{array}{l}\text { Total energy expenditure in sedentary } \\
\text { behaviors } \\
\text { Screen time (television and computer using) }\end{array}$ & $\begin{array}{l}\text { 3-day physical activity diary } \\
\text { US Youth Risk Behavior Surveillance Survey }\end{array}$ \\
\hline Nutritional habits & $\begin{array}{l}\text { Food items related to healthy and unhealthy } \\
\text { diet }\end{array}$ & Children's Eating Behavior questionnaire \\
\hline Sleep habits & Total sleep time & Questionnaire \\
\hline
\end{tabular}

\section{Measures}

Table 1 depicts research domains, phenotypes and instrumentation used in the various substudies of the Portuguese Healthy Families Study. Research foci were on physical growth, physical fitness, lifestyle and health markers, mirrored in various sets of phenotypes: biological characteristics (body shape, body composition, metabolic syndrome, bone health and health-related physical fitness), and behavioral characteristics (physical activity, sedentary behavior, nutrition and sleep habits). All measurements were made according to standardized protocols, and instrumentation was suited to field research with hundreds or thousands of subjects. Further, all team members were trained by the principal investigator, and when necessary by international co-investigators.

\section{Main Findings}

A summary of phenotypes, sample, aims, statistical analysis and software used in all studies is presented in Tables 2-5. Sample sizes varied from 107 to 3378 nuclear families (only two generations), that is, from 422 to 12,385 subjects; in siblings, sample sizes also varied from 333 pairs (679 subjects) to 540 pairs (1010 subjects). All published studies to date have used cross-sectional data; we have not yet analyzed data on bone health, nutrition and sleep habits. We relied on top-down genetic epidemiological approaches, and the results comprise measures of resemblance (intraclass correlation and heritability), as well as estimates of gene-by-environment interactions. Given the level of clustering in sibling data, we relied on multilevel models to estimate similarity across sib-types and fitted all models, controlling for the effects of different sets of covariates.

\section{Body Shape - Somatotype}

Body shape, or somatotype, can be defined as the overall representation of an individual's physique, irrespective of its size, and has historically been rooted in the field of constitutional psychology (Sheldon et al., 1940). Somatotype is objectively described in terms of three components based on the Heath-Carter anthropometric method (Heath \& Carter, 1967): endomorphy (relative fatness), mesomorphy (musculoskeletal robustness) and ectomorphy (physique linearity). These components are rated on a continuous scale, and from these it is possible to identify the physique dominance and classify individual somatotypes.

Human variation in somatotype has been widely investigated in a variety of settings (for an extensive summary, see Carter \& Heath, 1990). It has consistently been related to sports performance (Carter, 1982; Eiben, 1972; Giannopoulos et al., 2017; RyanStewart et al., 2018; Sterkowicz-Przybycien et al., 2019), and it has also been linked to health-related outcomes (Singh, 2007) such as coronary heart disease (Williams et al., 1997), metabolic syndrome (Katzmarzyk et al., 1998), blood pressure (Herrera et al., 2004) and osteoporosis (Saitoglu et al., 2007).

In our recent research with Portuguese data, two articles dealt with sibling resemblance in somatotype (Table 2). Vasques et al. (2006) sampled 366 sibling pairs aged 10-18 years from north-east mainland Portugal, whereas Pereira et al. (2017a) examined 520 sibling pairs aged 9-20 years from the north and central regions of mainland Portugal. Vasques et al. (2006) controlled their analysis only for age and sex, while Pereira et al. (2017a) controlled for an extensive set of covariates, including age, age $^{2}$, age $\mathrm{a}^{3}$, total physical activity (TPA), age-by-TPA, age ${ }^{2}$-by-TPA and by age ${ }^{3}$-by-TPA interactions, as well as socioeconomic status. However, the results are consistent between the two studies, with same-sex siblings 
Table 2. Summary of studies examining familial resemblance in body shape and body composition

\begin{tabular}{|c|c|c|c|c|c|}
\hline Reference & Aims & Sample & Age (mean age, age range) & Phenotypes & $\begin{array}{l}\text { Statistical analysis } \\
\text { (software) }\end{array}$ \\
\hline $\begin{array}{l}\text { Vasques et al. } \\
(2006)\end{array}$ & $\begin{array}{l}\text { To investigate the presence } \\
\text { of sibling similarity in body } \\
\text { shape, as well as on its } \\
\text { three-dimensional expression }\end{array}$ & $\begin{array}{l}366 \text { sibling pairs } \\
\text { (732 subjects) }\end{array}$ & $\begin{array}{l}\text { Girls }(13.0 ; \text { range }=10-18) \\
\text { Boys }(14.0 ; \text { range }=10-18)\end{array}$ & $\begin{array}{l}\text { Somatotype components: } \\
\text { - Endomorphy } \\
\text { - Ectomorphy } \\
\text { - Mesomorphy }\end{array}$ & $\begin{array}{l}\text { Pearson correlations } \\
\text { and Canonical } \\
\text { correlation (SPSS) }\end{array}$ \\
\hline $\begin{array}{l}\text { Pereira et al. } \\
(2017 a)\end{array}$ & $\begin{array}{l}\text { To (1) estimate sibling } \\
\text { resemblance in somatotype } \\
\text { taken as a whole, that is, as } \\
\text { a multivariate representation } \\
\text { of their physique and ( } 2 \text { ) } \\
\text { identify different sib-pair } \\
\text { (brother-brother, sister- } \\
\text { sister, brother-sister) } \\
\text { similarities in individual } \\
\text { somatotype components }\end{array}$ & $\begin{array}{l}520 \text { sibling pairs } \\
\text { (1058 subjects) }\end{array}$ & $\begin{array}{l}\text { Brother-brother (13.2; } \\
\text { range =9-20) } \\
\text { Brother-sister (13.0; } \\
\text { range =9-20) } \\
\text { Sister-sister }(12.9 ; \\
\text { range =9-20) }\end{array}$ & $\begin{array}{l}\text { Somatotype components: } \\
\text { - Endomorphy } \\
\text { - Ectomorphy } \\
\text { - Mesomorphy }\end{array}$ & $\begin{array}{l}\text { Intraclass correlation } \\
\text { (SUPERMIX) }\end{array}$ \\
\hline $\begin{array}{l}\text { Souza et al. } \\
(2011)\end{array}$ & $\begin{array}{l}\text { To identify the presence of } \\
\text { indirect transmission of } \\
\text { genetic factors between } \\
\text { parents and children in two } \\
\text { trunk fat phenotypes }\end{array}$ & $\begin{array}{l}107 \text { nuclear } \\
\text { families ( } 422 \\
\text { subjects) }\end{array}$ & $\begin{array}{l}\text { Fathers }(42.5 ; \text { range }=33-56) \\
\text { Mothers }(39.9 ; \text { range }=30-53) \\
\text { Sons }(12.9 ; \text { range }=7-25) \\
\text { Daughters }(13.5 ; \text { range }=7-25)\end{array}$ & $\begin{array}{l}\text { Relative }(\%) \text { and } \\
\text { absolute trunk fat (kg) }\end{array}$ & $\begin{array}{l}\text { Familial intraclass } \\
\text { correlations and } \\
\text { heritability (FCOR and } \\
\text { ASSOC modules of } \\
\text { S.A.G.E.) }\end{array}$ \\
\hline $\begin{array}{l}\text { de Chaves et al. } \\
(2014)\end{array}$ & $\begin{array}{l}\text { To (1) identify familial } \\
\text { resemblance in body fat, } \\
\text { blood pressure and total } \\
\text { physical activity, (2) estimate } \\
\text { the magnitude of their } \\
\text { genetic and environmental } \\
\text { influences and (3) investigate } \\
\text { shared familial aggregation } \\
\text { among these phenotypes }\end{array}$ & $\begin{array}{l}260 \text { nuclear } \\
\text { families ( } 802 \\
\text { subjects) }\end{array}$ & $\begin{array}{l}\text { Fathers }(43.1 ; \text { range }=31-57) \\
\text { Mothers }(40.3 ; \text { range }=27-56) \\
\text { Sons }(12.5 ; \text { range }=7-22) \\
\text { Daughters }(12.9 ; \text { range }=7-25)\end{array}$ & Body fat & $\begin{array}{l}\text { Familial intraclass } \\
\text { correlation and } \\
\text { heritability } \\
\text { (Generalized } \\
\text { Estimating Equations } \\
\text { of GESEE and SOLAR) }\end{array}$ \\
\hline $\begin{array}{l}\text { Santos et al. } \\
(2014 a)\end{array}$ & $\begin{array}{l}\text { To (1) estimate the } \\
\text { magnitude of the genetic } \\
\text { effects on body composition } \\
\text { traits and ( } 2 \text { ) examine the } \\
\text { Genotype } \times \text { Total Daily } \\
\text { Energy Expenditure, and } \\
\text { Genotype } \times \text { Daily Energy } \\
\text { Expenditure interactions that } \\
\text { may affect the impact of } \\
\text { physical activity on body } \\
\text { composition traits }\end{array}$ & $\begin{array}{l}294 \text { nuclear } \\
\text { families (958 } \\
\text { subjects) }\end{array}$ & $\begin{array}{l}\text { Fathers }(45.4 ; \text { range }=33-57) \\
\text { Mothers }(43.5 ; \text { range }=33-56) \\
\text { Sons }(14.7 ; \text { range }=9-20) \\
\text { Daughters }(14.4 ; \text { range }=9-20)\end{array}$ & Body fat & Heritability (SOLAR) \\
\hline
\end{tabular}

being more similar in physique than opposite-sex sibs, regardless of the component under scrutiny. Further, a moderate familial index was reported when somatotype was considered as a gestalt of body physique. These results highlight the key role of familial and genetic factors in regulating the expression of each physique component, as well as the somatotype as a whole. Further, these studies provide interesting contributions to better understand the complexities of shared and nonshared factors in the ways that siblings resemble each other in their physique. Yet, future research could connect, in a multivariate fashion, adolescents' somatotypes with their health-related physical fitness components, food behaviors, sedentariness and various health outcomes. If these links could be approached longitudinally, they would provide important information for more efficient intervention programs at school or sport clubs settings within their sports for all programs.

\section{Body Composition}

Across all of our Portuguese studies, body composition phenotypes were estimated with a reliable and valid instrument (Kabiri et al., 2015) — a portable bio-electrical impedance scale (TANITA
BC-418 MA Segmental Body Composition Analyzer, Tanita Corporation, Japan). Four studies with Portuguese nuclear families were published (Table 3): Fermino et al. (2008) and Souza et al. (2011) used 107 nuclear families, Santos et al. (2014b) examined 294 nuclear families and de Chaves et al. (2014) used 260 nuclear families. Familial correlations and heritabilities were estimated using S.A.G.E. v5.3 (2005) FCOR and ASSOC modules in the first two articles; in the third one we relied on GESEE v1 (Tregouet \& Tiret, 2000) as well as in SOLAR v4.0.1 (Almasy \& Blangero, 1998), whereas in the fourth study (Santos et al., 2014b), heritabilities and gene-by-environment interactions were exclusively computed in SOLAR v4.3.1 (Almasy \& Blangero, 1998). All of these parameter

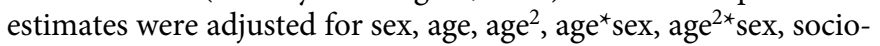
economic status and Body Mass Index (BMI) as needed.

Familial correlations for body composition are presented in Figure 1. For percentage of body fat, the lowest correlation was observed in spouses $(-0.14)$ and the highest in siblings $(0.28-0.34)$, but with some variation across studies. In Fermino et al. (2008), siblings were divided by sib-type (brother-brother, sister-sister and brother-sister) whereas in de Chaves et al. (2014) they were not, and we identified a similar trend in percentage of trunk fat such that 
Table 3. Summary of studies examining familial resemblance in metabolic syndrome

\begin{tabular}{|c|c|c|c|c|c|}
\hline Reference & Aims & Sample & Age (mean age, age range) & Phenotypes & $\begin{array}{l}\text { Statistical analysis } \\
\text { (software) }\end{array}$ \\
\hline Fermino et al. (2009) & $\begin{array}{l}\text { To estimate the magnitude } \\
\text { of genetic factors } \\
\text { contributing for variation in } \\
\text { BP values in the population }\end{array}$ & $\begin{array}{l}107 \text { nuclear families } \\
\text { (367 subjects) }\end{array}$ & $\begin{array}{l}\text { Fathers }(42.5 ; \text { range }=31-57) \\
\text { Mothers }(39.9 ; \text { range }=30-53) \\
\text { Sons }(12.8 ; \text { range }=7-22) \\
\text { Daughters }(13.5 ; \\
\text { range }=7-25)\end{array}$ & $\begin{array}{l}\text { Systolic and } \\
\text { diastolic blood } \\
\text { pressure }\end{array}$ & $\begin{array}{l}\text { Familial intraclass } \\
\text { correlation and } \\
\text { heritability (FCOR and } \\
\text { ASSOC modules of } \\
\text { S.A.G.E) }\end{array}$ \\
\hline $\begin{array}{l}\text { Santos, Katzmarzyk, } \\
\text { Diego et al. (2013) }\end{array}$ & $\begin{array}{l}\text { To estimate the magnitude } \\
\text { of genetic factors } \\
\text { responsible for the } \\
\text { architecture of metabolic } \\
\text { syndrome traits and (2) } \\
\text { study potential } G \times \mathrm{EE} \\
\text { interactions }\end{array}$ & $\begin{array}{l}294 \text { nuclear families } \\
\text { (958 subjects) }\end{array}$ & $\begin{array}{l}\text { Fathers }(45.4 ; \text { range }=33-57) \\
\text { Mothers }(43.5 ; \text { range }=33-56) \\
\text { Sons }(14.7 ; \text { range }=9-20) \\
\text { Daughters }(14.4 ; \\
\text { range }=9-20)\end{array}$ & $\begin{array}{l}\text { Waist } \\
\text { circumference } \\
\text { Systolic blood } \\
\text { pressure } \\
\text { Glucose } \\
\text { HDL-cholesterol } \\
\text { Triglycerides }\end{array}$ & $\begin{array}{l}\text { Familial intraclass } \\
\text { correlation and } \\
\text { heritability } \\
\text { (Generalized } \\
\text { Estimating Equations } \\
\text { of GESEE and SOLAR) }\end{array}$ \\
\hline $\begin{array}{l}\text { Santos Katzmarzyk, } \\
\text { Tregouet et al. (2013) }\end{array}$ & $\begin{array}{l}\text { To (1) estimate heritability } \\
\text { for each of the metabolic } \\
\text { syndrome indicators, and } \\
\text { (2) test the significance of } \\
\text { familial intratrait and cross- } \\
\text { trait correlations in } \\
\text { metabolic syndrome } \\
\text { markers }\end{array}$ & $\begin{array}{l}515 \text { nuclear families } \\
\text { (1363 subjects) }\end{array}$ & $\begin{array}{l}\text { Fathers }(45.4 ; \text { range }=33-57) \\
\text { Mothers }(43.5 ; \text { range }=33-56) \\
\text { Sons }(14.7 ; \text { range }=9-20) \\
\text { Daughters }(14.4 ; \\
\text { range }=9-20)\end{array}$ & $\begin{array}{l}\text { Waist } \\
\text { circumference } \\
\text { Systolic blood } \\
\text { pressure } \\
\text { Glucose } \\
\text { HDL-cholesterol } \\
\text { Triglycerides }\end{array}$ & $\begin{array}{l}\text { Familial intraclass } \\
\text { correlation and } \\
\text { heritability } \\
\text { (Generalized } \\
\text { Estimating Equations } \\
\text { of GESEE and SOLAR) }\end{array}$ \\
\hline De Chaves et al. (2014) & $\begin{array}{l}\text { To (1) identify familial } \\
\text { resemblance in body fat, } \\
\text { blood pressure and total } \\
\text { physical activity, and ( } 2 \text { ) } \\
\text { estimate the magnitude of } \\
\text { their genetic and } \\
\text { environmental influences, } \\
\text { and ( } 3 \text { ) investigate shared } \\
\text { familial aggregation among } \\
\text { these phenotypes }\end{array}$ & $\begin{array}{l}260 \text { nuclear families } \\
\text { (802 subjects) }\end{array}$ & $\begin{array}{l}\text { Fathers }(43.1 ; \text { range }=31-57) \\
\text { Mothers }(40.3 ; \text { range }=27-56) \\
\text { Sons }(12.5 ; \text { range }=7-22) \\
\text { Daughters }(12.9 ; \\
\text { range }=7-25)\end{array}$ & $\begin{array}{l}\text { Systolic and } \\
\text { diastolic blood } \\
\text { pressure }\end{array}$ & $\begin{array}{l}\text { Familial intraclass } \\
\text { correlation and } \\
\text { heritability } \\
\text { (Generalized } \\
\text { Estimating Equations } \\
\text { of GESEE and SOLAR) }\end{array}$ \\
\hline Pereira et al. (2019) & $\begin{array}{l}\text { To estimate sibling } \\
\text { resemblance in metabolic } \\
\text { syndrome markers }\end{array}$ & $\begin{array}{l}333 \text { sibling pairs } \\
\text { (679 subjects) }\end{array}$ & $\begin{array}{l}\text { Brother-brother (13.6; } \\
\text { range =9-20) } \\
\text { Brother-sister (13.4; } \\
\text { range =9-20) } \\
\text { Sister-sister (13.5; } \\
\text { range =9-20) }\end{array}$ & $\begin{array}{l}\text { Waist } \\
\text { circumference } \\
\text { Systolic blood } \\
\text { pressure } \\
\text { Glucose } \\
\text { HDL-cholesterol } \\
\text { Triglycerides }\end{array}$ & $\begin{array}{l}\text { Intraclass correlation } \\
\text { (STATA) }\end{array}$ \\
\hline
\end{tabular}

Note: $\mathrm{G} \times \mathrm{EE}=$ genotype by energy expenditure; HDL-cholesterol = high-density lipoprotein cholesterol.
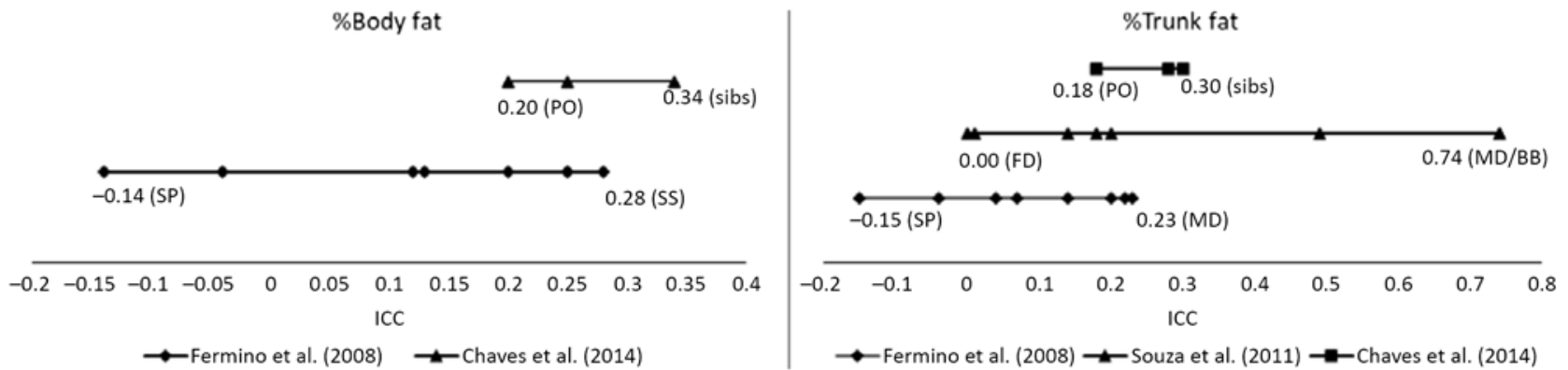

Fig. 1. Ranges of familial intraclass correlations coefficients (ICC) for body composition phenotypes.

Notes: $\mathrm{SP}=$ spouses, $\mathrm{PO}=$ parent-offsprings, $\mathrm{FD}=$ father-daughter, $\mathrm{MD}=$ mother-daughter, $\mathrm{Sibs}=$ siblings, $\mathrm{BB}=$ brother-brother, $\mathrm{SS}=$ sister-sister.

the lowest correlations were in spouses $(-0.15)$ and the highest for mother-daughter and brother-brother pairs (0.74). Heritability estimates in body composition phenotypes also varied across studies (Figure 2), ranging from .25 to .39 and .21 to .50 in percentage of body fat and percentage of trunk fat, respectively. Additionally, in Santos et al. (2014b), total daily energy expenditure (TDEE; $\mathrm{kcal} / \mathrm{kg}$ ) and daily energy expenditure (DEE; kcal) in body composition genetic regulation were tested using a gene-by-environment 


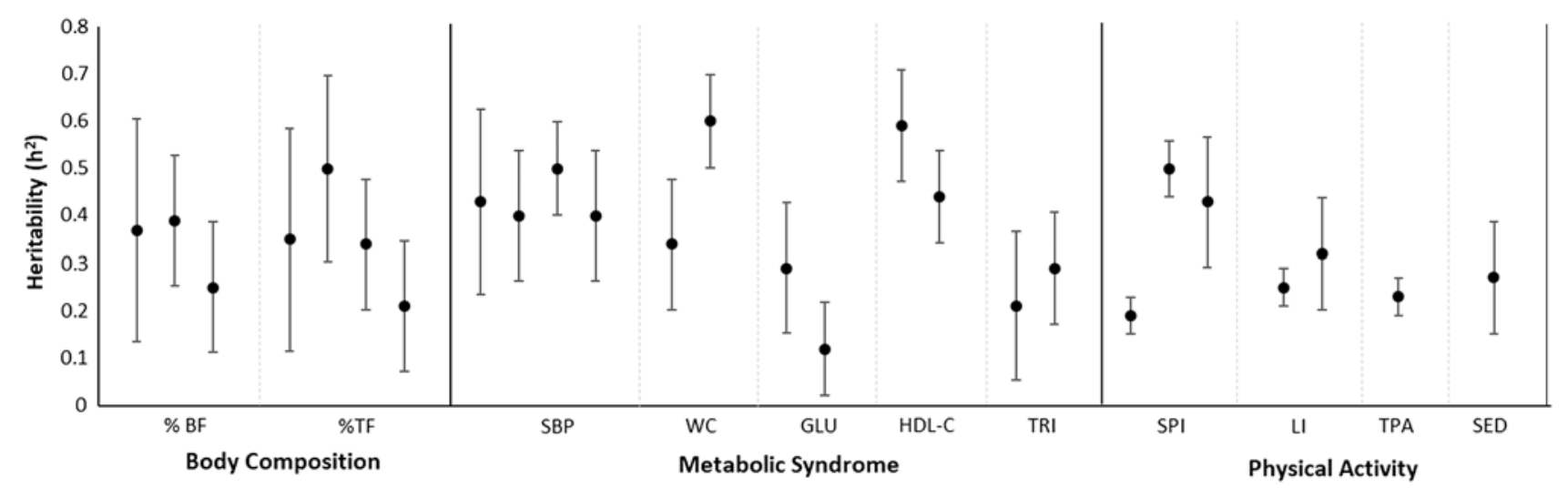

Fig. 2. Heritability estimates and corresponding $95 \%$ confidence intervals for phenotypes in all study domains.

Notes: \% BF = body fat percentage, $\% \mathrm{TF}=$ trunk fat percentage, SBP = systolic blood pressure, WC = waist circumference; GLU = glucose, HDL-C = HDL cholesterol, $\mathrm{TRI}=$ triglycerides, $\mathrm{SPI}=$ sport participation index, $\mathrm{LI}=$ leisure index, TPA = total physical activity, SED =sedentary time.

interactions $(\mathrm{G} \times \mathrm{TDEE}$ and $\mathrm{G} \times \mathrm{DEE})$. Results revealed significant interactions with all body composition phenotypes, thus indicating an interindividual variability in body composition expression, explained to some extent by an interaction between genotype and energy expenditure.

In summary, low-to-moderate resemblance among family members in body composition traits was observed, meaning that it is important to design effective and creative programs within the family orbit to especially prevent increases in body fat, given its known links to several diseases like cardiovascular disease (Despres, 2012), insulin resistance (Patel \& Abate, 2013), type 2 diabetes (Kleinert et al., 2018), hypertension (Chen et al., 2018) and metabolic syndrome (Kwon et al., 2017). Moreover, the significant interaction between genotype and energy expenditure in the expression of body traits was observed. Thus, a major point to note here is that physical activity promotes interindividual differences in body composition traits by genetic mediation. We foresee that future genetic research using top-down approaches with nuclear families, or even with sib-ships, should consider putative links of moderate-to-vigorous physical activity, food consumption behaviors and objective food eating habits, socioeconomic status, multiplicity of built environments and cultural diversity, together with various body composition phenotypes within a longitudinal perspective.

\section{Metabolic Syndrome}

Metabolic syndrome is defined as a constellation of interrelated pathophysiological risk factors, namely central adiposity, insulin resistance, dyslipidemia and hypertension, which increases the risk for cardiovascular diseases and type 2 diabetes (Alberti et al., 2006). Over the years, research has been marked by several attempts to develop criteria to define accurate cut-points in each of the metabolic syndrome markers so that precise prevalence estimates could be provided (Alberti et al., 2006). As metabolic syndrome is a forerunner to several noncommunicable diseases (Eckel et al., 2005) there has also been an increased interest in the study of these clustered risk factors in children and adolescents, given the observed increase in its prevalence within the pediatric population.

As most of our data collection was done in field settings, we relied on standardized protocols and validated instruments used to measure metabolic syndrome indicators. For example, systolic blood pressure was assessed using three consecutive measures (with a 2 or 3 min's interval between them) with an automatic digital Omron sphygmomanometer (Omron M6, hem 7001-E, Omron Healthcare); a finger-stick blood sample was collected to obtain high-density lipoprotein cholesterol (HDL-cholesterol), triglycerides and glucose using the Cholestech LDX point of care device (Cholestech Corporation, Hayward, CA, USA); finally, waist circumference was measured using a nonelastic anthropometric tape (Sanny, American Medical of Brazil, Brazil).

Three studies have data on all metabolic syndrome markers one study relied on a sample of siblings, whereas the other two included nuclear families. Furthermore, two other studies only used blood pressure indicators. Sample sizes varied from 107 to 515 nuclear families and the sibling study sampled 333 sibling pairs (Pereira et al., 2019). All studies adjusted their statistical analysis for several covariates - Santos et al. (2013a) and (2013b) used age $^{2}$, sex, age ${ }^{\star}$ sex, and age ${ }^{2 \star}$ sex, whereas Fermino et al. (2009) used age, sex, age ${ }^{2}$, age ${ }^{3}$, age ${ }^{*}$ sex, age ${ }^{2 *}$ sex and BMI; further, de Chaves et al. (2014) used sex, age, age ${ }^{2}$, age ${ }^{\star}$ sex, age ${ }^{2 \star}$ sex and Socioeconomic status (SES), while Pereira et al. (2019) used age ${ }^{2}$, BMI, maturity offset, fruit and vegetable consumption, sugary drink consumption, TPAy and muscular fitness and cardiorespiratory fitness scores.

Siblings showed higher similarity than other family members in all metabolic syndrome markers, except for glucose in the Santos et al. (2013b) study; where spousal resemblance was higher than sibling resemblance. The lowest familial similarity was found for glucose and triglycerides (heritability $\left[h^{2}\right]$ estimates lower than .30; Figure 3). The remaining markers revealed moderate $h^{2}$, with values ranging from .40 for systolic blood pressure to .60 for waist circumference. The heritability was lower in this study compared with that reported by Santos et al. $\left(2013 \mathrm{a} ; h^{2}=.34\right)$. These discrepancies may be linked to differences in sample sizes and to differences in family compositions, that is, different kin structure among studies. In any case, these studies provide a significant body of results regarding the influence of genetic and environmental factors on metabolic syndrome Therefore, when considering the intertwined effects of factors regulating metabolic syndrome expression, we believe that future family studies are needed to investigate putative associations between metabolic syndrome and objective physical activity measures, as well as physical fitness levels, nutritional behaviors and objective food consumption using longitudinal designs integrating top-down and bottom-up methodologies to better understand the complex works of nature and nurture on metabolic syndrome. 


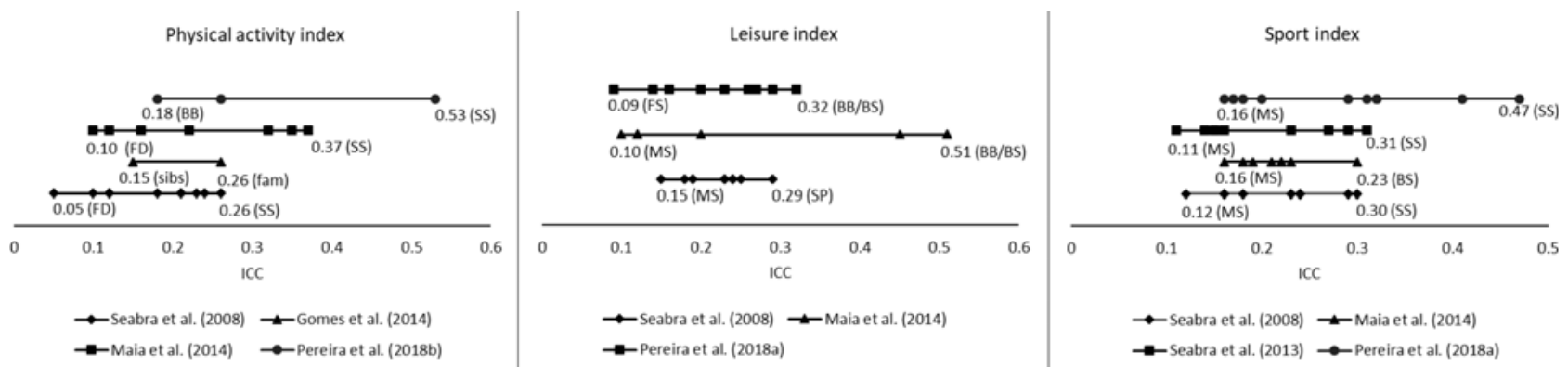

Fig. 3. Ranges of familial intraclass correlations coefficients (ICC) for physical activity phenotypes.

Notes: $\mathrm{SP}=$ spouses, $\mathrm{PO}=$ parent-offsprings, $\mathrm{FD}=$ father-daughter, $\mathrm{MD}=$ mother-daughter, $\mathrm{FS}=$ father-son, $\mathrm{MS}=\mathrm{mother}-\mathrm{son}$, fam $=$ family, $\mathrm{Sibs}=$ siblings, $\mathrm{BB}=$ brother - brother, $\mathrm{SS}=$ sister-sister .

\section{Physical Activity and Sedentary Behavior}

Physical activity can be defined as any bodily movement produced by skeletal muscles that results in energy expenditure (Caspersen et al., 1985). Previous research reported that adequate physical activity levels reduce the incidence of several noncommunicable diseases and premature mortality (Lee et al., 2012). On the other hand, high levels of sedentary behaviors (e.g. TV viewing, video game playing and computer use) have been shown to negatively impact health-related outcomes, regardless of the influence of other important factors such as diet and physical activity (de Rezende et al., 2014).

Our Portuguese research studies have had a special focus on studying physical activity and sedentary behavior using family data (Table 4). Sample sizes ranged from 206 to 3378 nuclear families and, as expected in large studies, we mostly relied on a simple method to assess physical activity - the Baecke questionnaire (Baecke et al., 1982) with its three domains: work/school physical activity, leisuretime physical activity and sport participation; further, a measure of TPA was generated by summing the individual scores in these domains. Sedentary behavior was obtained from three different questionnaires: The International Physical Activity questionnaire (Television viewing; Bassett, 2003); the 3-day physical activity diary (minutes spent in sedentary behaviors and energy expenditure in sedentary; Bouchard et al., 1983); the Baecke questionnaire (Physical Activity tertiles), namely the total time the subject used a personal computer per day (personal computer usage).

Further, different studies used different analytic software based on specific aims. For example, FCOR and ASSOC modules (Pereira et al., 2018a; Seabra et al., 2008, 2014), GESEE and SOLAR (de Chaves et al., 2014; Maia et al., 2014; Santos et al., 2014a), and multilevel models using SPSS and SuperMix (Gomes et al., 2014; Pereira et al., 2018b) were used. Similarly, adjusting for covariates was also different. For example, de Chaves et al. (2014), Maia et al. (2014), Pereira et al. (2018a), Seabra et al. $(2008,2014)$ and mostly adjusted for biological factors, whereas Pereira et al. (2018b) considered the joint effects of biological, behavioral and environmental characteristics.

Figure 2 shows familial/sibling correlations for TPA, leisure time and sports participation, and the results reveal a similar trend: father-daughter pairs have the lowest resemblance, and sister-sister pairs had the highest resemblance for TPA. For the leisure-time physical activity index, mother-son and father-son pairs had the lowest resemblance while brother-brother and brother-sister pairs had the highest resemblance. For the sports participation index (SPI), mother-son pairs had the lowest resemblance, whereas siblings had the highest. Heritability estimates for the three domains were generally low, ranging from .23 for TPA to .32 for the leisure-time physical activity index. Additionally, $h^{2}$ estimates for sedentary behavior phenotypes were also low - from .04 for daily computer use to .27 in sedentary time. Additionally, Pereira et al. (2018a) examined the stability of genetic factors for TPA and SPI from early (10-14 years) to late adolescence (15-19 years), and no significant differences were found across estimates: $h^{2}=.297$ and $.322, h^{2}=.413$ and .428 , for TPA and SPI, respectively.

In summary, our results showed a moderate genetic influence on physical activity and sedentary behavior. Additionally, heritability tends to remain stable from early to late adolescence. Further, the propensity to be physically active and/or sedentary is mostly determined by the interaction between genetic endowments and shared environmental characteristics. These findings provide a fertile ground for novel family research opportunities, longitudinally based, and using more detailed information on the specificities of shared and unique environments linked to physical activity and sedentariness. These have to link quantitative as well as qualitative information and probe into the stability, or change, of these different environments.

\section{Health-Related Physical Fitness}

Broadly speaking, physical fitness is an individual attribute that allows a person to carry out his/her daily activities without undue fatigue and with adequate energy reserves to enjoy leisure pursuits (Malina \& Katzmarzyk, 2006). It has been suggested that physical fitness is an important health marker (Ortega et al., 2018), and there is growing evidence showing that adequate physical fitness levels are associated with the prevention of overweight during childhood and adolescence (Rodrigues et al., 2016), with cognitive development (Haapala 2013), as well as academic achievement (Eveland-Sayers et al., 2009).

Our physical fitness studies relied on samples of siblings (Table 5). Vasques et al. (2007) used the following tests: curl-up, push-up, trunk-lift and 1-mile run/walk in a sample of 366 sibs (732 subjects) aged 10-18 years, whereas Pereira et al. (2017b) used 540 sibs (1101 subjects) aged 9-20 years, and relied on the following tests: waist circumference, percentage of body fat, handgrip strength, standing long jump, 50-yard dash, shuttle run and 1-mile run. In addition, statistical procedures used for data analysis also varied across the different studies. Vasques et al. (2007) used Pearson and canonical correlations controlling for age, while Pereira et al. (2017b) estimated intraclass correlation coefficients from multilevel models after adjustment for a number of covariates, including age, age ${ }^{2}$, maturity offset, TPA, TV viewing, socioeconomic status and a series of interactions of age with sib-types. 
Table 4. Summary of studies examining familial resemblance in physical activity and sedentary behavior

\begin{tabular}{|c|c|c|c|c|c|}
\hline Reference & Aims & Sample & Age (mean age, age range) & Phenotypes & $\begin{array}{l}\text { Statistical analysis } \\
\text { (software) }\end{array}$ \\
\hline Seabra et al. (2008) & $\begin{array}{l}\text { To (1) estimate familial } \\
\text { aggregation, and ( } 2 \text { ) quantify } \\
\text { the contribution of genetic } \\
\text { and environmental factors on } \\
\text { physical activity habits of } \\
\text { Portuguese families }\end{array}$ & $\begin{array}{l}2375 \text { nuclear } \\
\text { families ( } 9500 \\
\text { subjects) }\end{array}$ & $\begin{array}{l}\text { Fathers }(45.5 ; \text { range }=33-57) \\
\text { Mothers }(42.9 ; \text { range }=32-56) \\
\text { Sons }(16.2 ; \text { range }=32-56) \\
\text { Daughters }(16.0 ; \text { range }=32-56)\end{array}$ & $\begin{array}{l}\text { Total physical } \\
\text { activity index, } \\
\text { school/work, sport } \\
\text { and leisure index }\end{array}$ & $\begin{array}{l}\text { Familial intraclass } \\
\text { correlation and } \\
\text { heritability (FCOR } \\
\text { module of S.A.G.E } \\
\text { and SOLAR) }\end{array}$ \\
\hline de Chaves et al. (2014) & $\begin{array}{l}\text { To (1) identify familial } \\
\text { resemblance in total physical } \\
\text { activity, (2) estimate the } \\
\text { magnitude of their genetic } \\
\text { and environmental } \\
\text { influences, and (3) investigate } \\
\text { shared familial aggregation } \\
\text { among these phenotypes }\end{array}$ & $\begin{array}{l}260 \text { nuclear } \\
\text { families ( } 802 \\
\text { subjects) }\end{array}$ & $\begin{array}{l}\text { Fathers }(43.1 ; \text { range }=31-57) \\
\text { Mothers }(40.3 ; \text { range }=27-56) \\
\text { Sons }(12.5 ; \text { range }=7-22) \\
\text { Daughters }(12.9 ; \text { range }=7-25)\end{array}$ & $\begin{array}{l}\text { Total physical } \\
\text { activity index }\end{array}$ & $\begin{array}{l}\text { Familial intraclass } \\
\text { correlation and } \\
\text { heritability } \\
\text { (Generalized } \\
\text { Estimating } \\
\text { Equations of } \\
\text { GESEE and } \\
\text { SOLAR) }\end{array}$ \\
\hline Gomes et al. (2014) & $\begin{array}{l}\text { To investigate predictors and } \\
\text { sources of variance of } \\
\text { physical activity levels in } \\
\text { nuclear families using } \\
\text { multilevel modeling }\end{array}$ & $\begin{array}{l}2661 \text { nuclear } \\
\text { families }(10,644 \\
\text { subjects) }\end{array}$ & $\begin{array}{l}\text { Fathers }(45.5 ; \text { range }=33-57) \\
\text { Mother }(43.0 ; \text { range }=32-56) \\
\text { Sibs }(16.2 ; \text { range }=10-18)\end{array}$ & $\begin{array}{l}\text { Total physical } \\
\text { activity index }\end{array}$ & $\begin{array}{l}\text { Intraclass } \\
\text { correlation (HLM) }\end{array}$ \\
\hline Maia et al. (2014) & $\begin{array}{l}\text { To (1) assess whether } \\
\text { physical activity shows } \\
\text { familial aggregation in the } \\
\text { Portuguese population and } \\
\text { (2) disentangle the exact } \\
\text { pattern of familial } \\
\text { resemblance }\end{array}$ & $\begin{array}{l}2661 \text { nuclear } \\
\text { families }(10,644 \\
\text { subjects) }\end{array}$ & $\begin{array}{l}\text { Fathers }(45.6 ; \text { range }=32-57) \\
\text { Mothers }(43.1 ; \text { range }=32-56) \\
\text { Sons }(16.2 ; \text { range }=10-18) \\
\text { Daughters }(16.1 ; \text { range }=10-18)\end{array}$ & $\begin{array}{l}\text { Total physical } \\
\text { activity index, } \\
\text { School/work, sport } \\
\text { and leisure index }\end{array}$ & $\begin{array}{l}\text { Familial intraclass } \\
\text { correlation } \\
\text { (Generalized } \\
\text { Estimating } \\
\text { Equations of } \\
\text { GESEE software) }\end{array}$ \\
\hline Seabra et al. (2014) & $\begin{array}{l}\text { To (1) estimate familial } \\
\text { aggregation, and ( } 2 \text { ) quantify } \\
\text { the genetic and } \\
\text { environmental contribution } \\
\text { - the phenotypic variation in } \\
\text { sports participation among } \\
\text { Portuguese families }\end{array}$ & $\begin{array}{l}2375 \text { nuclear } \\
\text { families ( } 9500 \\
\text { subjects) }\end{array}$ & $\begin{array}{l}\text { Fathers }(45.5 ; \text { range }=33-57) \\
\text { Mothers }(42.9 ; \text { range }=32-56) \\
\text { Sons }(16.2 ; \text { range }=10-18) \\
\text { Daughters }(16.0 ; \text { range } 10-18)\end{array}$ & Sport index & $\begin{array}{l}\text { Familial intraclass } \\
\text { correlation and } \\
\text { heritability (FCOR } \\
\text { module of S.A.G.E } \\
\text { and SOLAR) }\end{array}$ \\
\hline Pereira et al. (2018a) & $\begin{array}{l}\text { To investigate how consistent } \\
\text { genetic factors are, as } \\
\text { measured by heritability } \\
\text { estimates, in the leisure-time } \\
\text { physical activity index and } \\
\text { sport participation index from } \\
\text { early (10-14 years) to late } \\
\text { adolescence (15-19 years) }\end{array}$ & $\begin{array}{l}3378 \text { nuclear } \\
\text { families }(12,385 \\
\text { subjects) }\end{array}$ & $\begin{array}{l}\text { Fathers }(43.7 ; \text { range }=31-57) \\
\text { Mothers }(41.5 ; \text { range }=27-56) \\
\text { Sons }(14.2 ; \text { range }=10-19) \\
\text { Daughters }(14.2 ; \text { range }=10-19)\end{array}$ & $\begin{array}{l}\text { Sport and leisure } \\
\text { index }\end{array}$ & $\begin{array}{l}\text { Familial intraclass } \\
\text { correlation and } \\
\text { heritability } \\
\text { estimates (FCOR } \\
\text { and ASSOC } \\
\text { modules of } \\
\text { S.A.G.E) }\end{array}$ \\
\hline Pereira et al. (2018b) & $\begin{array}{l}\text { To (1) investigate the } \\
\text { relationships of biological, } \\
\text { behavioral, familial and } \\
\text { environmental characteristics } \\
\text { with siblings physical activity } \\
\text { levels and (2) analyze the } \\
\text { intrapair resemblance in } \\
\text { physical activity }\end{array}$ & $\begin{array}{l}390 \text { sibling pairs } \\
\text { (834 subjects) }\end{array}$ & $\begin{array}{l}\text { Brother-brother }(13.3 ; \\
\text { range }=9-20) \\
\text { Brother-sister }(12.9 ; \text { range }=9-20) \\
\text { Sister-sister }(13.0 ; \text { range }=9-20)\end{array}$ & $\begin{array}{l}\text { Total physical } \\
\text { activity index }\end{array}$ & $\begin{array}{l}\text { Intraclass } \\
\text { correlation } \\
\text { (STATA) }\end{array}$ \\
\hline Santos et al. (2014a) & $\begin{array}{l}\text { To (1) estimate the } \\
\text { magnitude of genetic factors } \\
\text { responsible for variation in } \\
\text { sedentary behavior } \\
\text { phenotypes and ( } 2 \text { ) study } \\
\text { potential genotype-by-sex } \\
\text { and genotype-by-age } \\
\text { interactions influencing } \\
\text { sedentary behaviors }\end{array}$ & $\begin{array}{l}339 \text { nuclear } \\
\text { families (1345 } \\
\text { subjects) }\end{array}$ & $\begin{array}{l}\text { Fathers }(45.4 ; \text { range }=33-57) \\
\text { Mothers }(43.5 ; \text { range }=33-56) \\
\text { Sons }(14.7 ; \text { range }=9-20) \\
\text { Daughters }(14.4 ; \text { range }=9-20)\end{array}$ & $\begin{array}{l}\text { Total daily sedentary } \\
\text { energy expenditure } \\
\text { Daily PC using } \\
\text { Daily TV watching } \\
\text { Sedentary time } \\
\text { per day } \\
\text { Sitting time per day } \\
\text { Physical activity } \\
\text { tertiles }\end{array}$ & $\begin{array}{l}\text { Heritability } \\
\text { estimates (SOLAR) }\end{array}$ \\
\hline
\end{tabular}

In both studies, sibling similarity was specific to each physical fitness test and depended on the statistical adjustments made for biological, behavioral and environmental characteristics. However, in general, a similar pattern emerged: same-sex siblings showed the greatest resemblance for all physical fitness tests. For example, Vasques et al. (2007) reported that sibling similarity ranged from .22 (curl-up) to .49 (1-mile run/walk) in same-sex siblings, and from .02 (trunk-lift) to .14 (curl-up) in opposite-sex siblings. Further, Pereira et al. (2017b) reported that resemblance varied from .11 (1-mile run/walk) to .54 (handgrip strength) in 
Table 5. Summary studies examining familial resemblance in physical fitness

\begin{tabular}{|c|c|c|c|c|c|}
\hline Reference & Aims & Sample & Age (mean age, age range) & Phenotypes & $\begin{array}{l}\text { Statistical analysis } \\
\text { (software) }\end{array}$ \\
\hline Vasques et al. (2007) & $\begin{array}{l}\text { To analyze sibling similarity in } \\
\text { levels physical fitness }\end{array}$ & $\begin{array}{l}366 \text { sibling pairs } \\
\text { (732 subjects) }\end{array}$ & $\begin{array}{l}\text { Girls }(14.2 ; \text { range }=10-18) \\
\text { Boys }(14.0 ; \text { range }=10-18)\end{array}$ & $\begin{array}{l}\text { Curl-up } \\
\text { Push-up } \\
\text { Trunk-lift } \\
\text { 1-mile run/walk } \\
\text { Total physical } \\
\text { fitness }\end{array}$ & $\begin{array}{l}\text { Pearson } \\
\text { correlations and } \\
\text { canonical } \\
\text { correlation (SPSS) }\end{array}$ \\
\hline
\end{tabular}

same-sex siblings, while in opposite-sex siblings no resemblance was found in unadjusted intraclass correlations for all fitness tests. Yet, when the model was fully adjusted, the highest resemblance value (.14) was observed for the 1-mile run/walk.

Overall, these results highlight the importance of explaining interindividual variation in physical fitness levels considering the combined effects of genetic factors as well as shared and unique environmental factors. Future research should use longitudinal nuclear family data (or using only sib-ships) to examine this complex web of putative links (body composition, physical activity and sedentariness) that may influence physical fitness changes over time.

\section{Summary}

The studies we have conducted under the umbrella of the Portuguese Healthy Family Study have resulted in several important results:

1. Sibling similarity in somatotype is moderate and consistent among the sibling studies, suggesting a degree of genetic regulation of body shape.

2. Resemblance in body composition phenotypes is moderately influenced by genetic factors. Energy expenditure interacts with genotype promoting a substantial degree of heterogeneity in body composition.

3. Glucose and triglycerides demonstrate the least familial similarity, whereas waist circumference, blood pressure and HDL-cholesterol showed moderate resemblance. These results shed light into the complex intertwined effects of genes and the environment in the expression of metabolic syndrome in family members.

4. Familial resemblance (shared genes and environments) in physical activity domains (TPA, sports index and leisure time) as well as in sedentary behaviors was low. Further, genetic factors regulating leisure-time physical activity as well as sports index were stable across adolescence.

5. Sibling resemblance in physical fitness is specific to each fitness test. Further, same-sex siblings are substantially more alike than opposite-sex siblings.

Acknowledgements. The authors express their gratitude to all the participants in the Portuguese Healthy Family Study.

Financial support. This work was supported by the FCT - Foundation for Science and Technology. The authors thank them for granting this research (PTDC/DES/67569/2006 and FCOMP-01-0124FEDEB-09608).

Conflict of interest. None.
Ethical standards. The authors assert that all procedures contributing to this work comply with the ethical standards of the relevant national and institutional committees on human experimentation and with the Helsinki Declaration of 1975 , as revised in 2008 .

\section{References}

Alberti, K. G., Zimmet, P., \& Shaw, J. (2006). Metabolic syndrome - A new world-wide definition. A Consensus Statement from the International Diabetes Federation. Diabetic Medicine, 23, 469-480.

Almasy, L., \& Blangero, J. (1998). Multipoint quantitative-trait linkage analysis in general pedigrees. The American Journal of Human Genetics, 62, 1198-1211.

Baecke, J. A., Burema, J., \& Frijters, J. E. (1982). A short questionnaire for the measurement of habitual physical activity in epidemiological studies. American Journal of Clinical Nutrition, 36, 936-942.

Bassett, D. R., Jr. (2003). International physical activity questionnaire: 12-country reliability and validity. Medicine and Science in Sports and Exercise, 35, 1396.

Bouchard, C., Tremblay, A., Leblanc, C., Lortie, G., Savard, R., \& Theriault, G. (1983). A method to assess energy expenditure in children and adults. The American Journal of Clinical Nutrition, 37, 461-467.

Campos, M. A. O. A., Maia, J. A. R., da Silva, R. G., Seabra, A., Lopes, V. P., Freitas, D., .. B Bacalhau, F. (2007). Combata a síndrome metabólica. Cuide da sua família e faça actividade física. Açores, Portugal: Direcção do Desporto da Região Autónoma dos Açores.

Campos, M. A. O. A., Maia, J. A. R., Seabra, A., Freitas, D. L., da Silva, R. G., \& Lopes, V. P. (2007). Actividade física e componentes da síndrome metabólica : um estudo em famílias açorianas. Açores, Portugal: Direcção Regional do Desporto da Região Autónoma dos Açores.

Carter, J. E. L. (1982). Somatotypes of olympic athletes from 1948 to 1976. In J. E. Carter (Ed.), Physical structure of olympic athletes. Part II: Kinanthropometry of olympic athletes (pp. 80-109). Basel, Switzerland: Karger AG.

Carter, J. E. L., \& Heath, B. H. (1990). Somatotyping - Development and applications. Cambridge, UK: Cambridge University Press.

Caspersen, C. J., Powell, K. E., \& Christenson, G. M. (1985). Physical activity, exercise, and physical fitness: Definitions and distinctions for health-related research. Public Health Reports, 100, 126-131.

Chen, Y., Liang, X., Zheng, S., Wang, Y., \& Lu, W. (2018). Association of body fat mass and fat distribution with the incidence of hypertension in a population-based Chinese cohort: A 22-year follow-up. Journal of the American Heart Association, 7, e007153.

de Chaves, R. N., Baxter-Jones, A., Santos, D., Gomes, T. N., dos Santos, F. K., de Souza, M. C., ... Maia, J. (2014). Clustering of body composition, blood pressure and physical activity in Portuguese families. Annals of Human Biology, 41, 159-167.

de Rezende, L. F., Rodrigues Lopes, M., Rey-López, J. P., Matsudo, V. K., \& Luiz Odo, C. (2014). Sedentary behavior and health outcomes: An overview of systematic reviews. PloS One, 9, e105620.

Despres, J. P. (2012). Body fat distribution and risk of cardiovascular disease: An update. Circulation, 126, 1301-1313. 
Eckel, R. H., Grundy, S. M., \& Zimmet, P. Z. (2005). The metabolic syndrome. Lancet, 365, 1415-1428.

Eiben, O. G. (1972). The physique of woman athletes. Budapest, Hungary: Hungarian Scientific Council for Physical Education.

Eveland-Sayers, B. M., Farley, R. S., Fuller, D. K., Morgan, D. W., \& Caputo, J. L. (2009). Physical fitness and academic achievement in elementary school children. Journal of Physical Activity and Health, 6, 99-104.

Fermino, R. C., Seabra, A., Garganta, R., \& Maia, J. A. R. (2009). Fatores genéticos na agregação familiar da pressão arterial de famílias nucleares portuguesas. Arquivos Brasileiros de Cardiologia, 92, 209-215.

Fermino, R. C., Seabra, A., Garganta, R., Valdivia, A. B., \& Maia, J. (2008). Um estudo de genética quantitativa sobre agregação familiar na composição corporal de famílias nucleares portuguesas. Revista Portuguesa de Ciências do Desporto, 8, 77-84.

Giannopoulos, N., Vagenas, G., Noutsos, K., Barzouka, K., \& Bergeles, N. (2017). Somatotype, level of competition, and performance in attack in elite male volleyball. Journal of Human Kinetics, 58, 131-140.

Gomes, T. N., Dos Santos, F. K., Garganta, R. M., Kenny, D. A., Katzmarzyk, P. T., \& Maia, J. A. (2014). Multi-level modelling of physical activity in nuclear families. Annals of Human Biology, 41, 138-144.

Haapala, E. A. (2013). Cardiorespiratory fitness and motor skills in relation to cognition and academic performance in children - A review. Journal of Human Kinetics, 36, 55-68.

Heath, B. H., \& Carter, J. E. (1967). A modified somatotype method. American Journal of Physical Anthropology, 27, 57-74.

Herrera, H., Rebato, E., Hernandez, R., Hernandez-Valera, Y., \& AlfonsoSanchez, M. A. (2004). Relationship between somatotype and blood pressure in a group of institutionalized Venezuelan elders. Gerontology, 50, 223-229.

Kabiri, L. S., Hernandez, D. C., \& Mitchell, K. (2015). Reliability, validity, and diagnostic value of a pediatric bioelectrical impedance analysis scale. Childhood Obesity, 11, 650-655.

Katzmarzyk, P. T., Malina, R. M., Song, T. M. K., \& Bouchard, C. (1998). Somatotype and indicators of metabolic fitness in youth. American Journal of Human Biology, 10, 341-350.

Kleinert, M., Clemmensen, C., Hofmann, S. M., Moore, M. C., Renner, S., Woods, S. C., ... Tschöp, M. H. (2018). Animal models of obesity and diabetes mellitus. Nature Reviews Endocrinology, 14, 140.

Kwon, H., Kim, D., \& Kim, J. S. (2017). Body fat distribution and the risk of incident metabolic syndrome: A longitudinal cohort study. Scientific Reports, 7, 10955.

Lee, I. M., Shiroma, E. J., Lobelo, F., Puska, P., Blair, S. N., \& Katzmarzyk, P. T. (2012). Effect of physical inactivity on major non-communicable diseases worldwide: An analysis of burden of disease and life expectancy. Lancet, 380, 219-229.

Maia, J., Freitas, D. L., \& Silva, C. (2008). Camacha saudável: Projecto. Porto, Portugal: Faculdade de Desporto, Universidade do Porto.

Maia, J., Gomes, T. N., Tregouet, D. A., \& Katzmarzyk, P. T. (2014). Familial resemblance of physical activity levels in the Portuguese population. Journal of Science and Medicine in Sport, 17, 381-386.

Maia, J., Seabra, A., \& Garganta, R. (2009). Vouzela activo: um olhar sobre o crescimento, desenvolvimento e saúde de crianças, jovens e famílias do concelho de Vouzela. Porto, Portugal: Faculdade de Desporto da Universidade do Porto.

Malina, R. M., \& Katzmarzyk, P. T. (2006). Physical activity and fitness in an international growth standard for preadolescent and adolescent children. Food and Nutrition Bulletin, 27, S295-S313.

Ortega, F., Cadenas-Sanchez, C., Lee, D., Ruiz, J., Blair, S., \& Sui, X. (2018). Fitness and fatness as health markers through the lifespan: An overview of current knowledge. Progress in Preventive Medicine, 3, e0013.

Patel, P., \& Abate, N. (2013). Body fat distribution and insulin resistance. Nutrients, 5, 2019-2027.

Pereira, S., Katzmarzyk, P. T., Gomes, T. N., Buranarugsa, R., Moura-DosSantos, M. A., Hedeker, D., \& Maia, J. (2019). Sibling similarity in metabolic syndrome: The Portuguese sibling study on growth, fitness, lifestyle and health. Behavior Genetics, 49, 299-309.

Pereira, S., Katzmarzyk, P. T., Gomes, T. N., Elston, R., \& Maia, J. (2018a). How consistent are genetic factors in explaining leisure-time physical activity and sport participation? The Portuguese Healthy Families Study. Twin Research and Human Genetics, 21, 369-377.
Pereira, S., Katzmarzyk, P. T., Gomes, T. N., Souza, M., Chaves, R. N., Santos, F. K., ... Maia, J. A. (2018b). Resemblance in physical activity levels: The Portuguese sibling study on growth, fitness, lifestyle, and health. American Journal of Human Biology, 30, e23061.

Pereira, S., Katzmarzyk, P. T., Gomes, T. N., Souza, M., Chaves, R. N., Santos, F. K. D., .. Maia, J. A. R. (2017a). Multilevel modelling of somatotype components: The Portuguese sibling study on growth, fitness, lifestyle and health. Annals of Human Biology, 44, 316-324.

Pereira, S., Todd Katzmarzyk, P., Gomes, T. N., Souza, M., Chaves, R. N., Dos Santos, F. K., ... Maia, J. (2017b). A multilevel analysis of health-related physical fitness. The Portuguese sibling study on growth, fitness, lifestyle and health. PloS One, 12, e0172013.

Rodrigues, L., Stodden, D., \& Lopes, V. (2016). Developmental pathways of change in fitness and motor competence are related to overweight and obesity status at the end of primary school. Journal of Science and Medicine in Sport, 19, 87-92.

Ryan-Stewart, H., Faulkner, J., \& Jobson, S. (2018). The influence of somatotype on anaerobic performance. PloS One, 13, e0197761.

S.A.G.E. 5.3. (2005). Statistical analysis for genetic epidemiology. Retrieved from http://darwin.cwru.edu/sage/

Saitoglu, M., Ardicoglu, O., Ozgocmen, S., Kamanli, A., \& Kaya, A. (2007). Osteoporosis risk factors and association with somatotypes in males. Archives of Medical Research, 38, 746-751.

Santos, D. M., Katzmarzyk, P. T., Diego, V. P., Blangero, J., Souza, M. C., Freitas, D. L., .. Maia, J. A. (2014a). Genotype by sex and genotype by age interactions with sedentary behavior: The Portuguese healthy family study. PloS One, 9, e110025.

Santos, D. M., Katzmarzyk, P. T., Diego, V. P., Gomes, T. N., Santos, F. K., Blangero, J., \& Maia, J. A. (2014b). Genotype by energy expenditure interaction and body composition traits: The Portuguese healthy family study. BioMed Research International, 2014, Article ID 845207.

Santos, D. M., Katzmarzyk, P. T., Diego, V. P., Souza, M. C., Chaves, R. N., Blangero, J., \& Maia, J. A. (2013a). Genotype by energy expenditure interaction with metabolic syndrome traits: The Portuguese healthy family study. PloS One, 8, e80417.

Santos, D. M., Katzmarzyk, P. T., Tregouet, D. A., Gomes, T. N., Santos, F. K., \& Maia, J. A. (2013b). Familial aggregation of metabolic syndrome indicators in Portuguese families. BioMed Research International, 2013, Article ID 314823.

Seabra, A. F., Mendonca, D. M., Goring, H. H., Thomis, M. A., \& Maia, J. A. (2008). Genetic and environmental factors in familial clustering in physical activity. European Journal of Epidemiology, 23, 205-211.

Seabra, A. F., Mendonca, D. M., Goring, H. H., Thomis, M. A., \& Maia, J. A. (2014). Genetic influences of sports participation in Portuguese families. European Journal of Sport Science, 14, 510-517.

Sheldon, W. H., Stevens, S. S., \& Tucker, W. B. (1940). The varieties of human physique. New York, NY: Harper and Brothers.

Singh, S. P. (2007). Somatotype and disease - A review. In V. Bhasin \& M. K. Bhasin (Eds.), Anthropology today - Trends, scope and applications (pp. 251-261). Delhi, India: Kamla-Raj Enterprises.

Souza, M., Chaves, R., Santos, D., Fermino, R., Garganta, R., Seabra, A., \& Maia, J. (2011). Agregação familiar na adiposidade do tronco: um estudo em famílias nucleares portuguesas. Revista Brasileira De Educação Física E Esporte, 25, 153-161.

Sterkowicz-Przybycien, K., Sterkowicz, S., Biskup, L., Zarow, R., Kryst, L., \& Ozimek, M. (2019). Somatotype, body composition, and physical fitness in artistic gymnasts depending on age and preferred event. PloS One, 14, e0211533.

Tregouet, D., \& Tiret, L. (2000). Applications of the estimating equations theory to genetic epidemiology: A review. Annals of Human Genetics, 64, 1-14.

Vasques, C., Lopes, V. P., Seabra, A., Fermino, R., \& Maia, J. (2007). Semelhança fraterna nos níveis de aptidão física. Revista Portuguesa de Ciências do Desporto, 7, 9-17.

Vasques, C., Lopes, V. P., Seabra, A., Silva, S., \& Maia, J. A. (2006). Semelhança somatotipológica entre irmãos. Revista Brasileira de Cineatropometria e Desempenho Humano, 8, 23-29.

Williams, S. R., Jones, E., Bell, W., Davies, B., \& Bourne, M. W. (1997). Body habitus and coronary heart disease in men. A review with reference to methods of body habitus assessment. European Heart Journal, 18, 376-393. 